\title{
Dampingan Komunitas Pengusaha Tahu Melalui Pemanfaatan Bungkil Kedelai menjadi Kerupuk untuk Meningkatkan Nilai Jual Bungkil Kedelai di Desa Purwodadi
}

\author{
Lilit Biati, Sofi Faiqotul Hikmah \\ Institut Agama Islam Darussalam Blokagung Banyuwangi \\ lilitbiati@gmail.com, sofiefaiqotul@gmail.com
}

\begin{abstract}
:
Purwodadi Village is a village in the Banyuwangi Regency which is located in the central region, less than $48 \mathrm{~km}$ from the center of the regency administration to the west. Along the way to the village of Purwodadi brought by the expanse of rice fields. The economy of Purwodadi Village residents is concentrated in the agricultural sector with a livelihood of 800 people and around 615 farm workers. soybean meal is a potential that can be developed to increase farmers, especially tofu production in Tempurejo Hamlet, Purwodadi Village. This soybean cake cracker product has been promoted directly by the Head of Purwodadi Village for developed communities, starting with PKK mothers, housewives who want to open an entrepreneur. This program can run successfully because it is supported by the natural potential produced by the pulp that is the main ingredient of this program. Can be used to improve the economy of the Purwodadi Village community. From some of the programs that we have done during the implementation of community service programs in the Purwodadi Village community. The community is needed by the community to help advance and prosper the Purwodadi Village.
\end{abstract}

Keyword: empowerment, soybean meal, selling value

\section{Pendahuluan}

Desa Purwodadi adalah sebuah desa di wilayah Kabupaten Banyuwangi yang terletak di wilayah tengah, tepatnya kurang lebih $48 \mathrm{~km}$ dari pusat pemerintahan kabupaten ke arah barat. Sepanjang perjalanan menuju Desa Purwodadi dikelilingi oleh hamparan persawahan yang didominasi oleh jeruk, buah naga dan cabai merah. Sebagian besar mata pencaharian penduduk Desa Purwodadi adalah petani. Perekonomian warga Desa Purwodadi tumpu pada sektor pertanian dengan mata pencaharian mayoritas sebagai petani yaitu sekitar 800 orang dan sebagai buruh tani yaitu sekitar 615 orang.(Purwodadi, 2017) Sedang yang bekerja 
sebagai buruh bangunan sekitar 750 orang. Selain itu jumlah penduduk bermata pencaharian lain di luar sektor pertanian meliputi: Sebagai pekerja sektor informal lainnya yang terdiri dari tukang batu, tukang, kayu, sopir, montir, pedagang keliling dan lain-lain sebagai PNS/TNI/POLRI sebagai guru sebagai pedagang dan sebagai pensiunan sebanyak .

Desa Purwodadi adalah desa yang sebagian besar wilayahnya berupa lahan pertanian, yakni sekitar 80,13 persen dari seluruh luas wilayah desa. Selebihnya adalah berupa wilayah permukiman, tanah wakaf dan tanah tidak produktif lainnya.(Purwodadi, 2017)

Di samping itu perekonomian desa selama ini bertumpu pada sektor pertanian dan sektor informal lainnya, dengan mayoritas penduduk bermatapencaharian sebagai petani, buruh tani dan pekerja sektor informal. Dengan demikian potensi Sumber Daya Alam yang bisa dimanfaatkan atau digali secara maksimal di Desa Purwodadi meliputi: Potensi sektor pertanian, sektor peternakan dan sektor industri. Potensi Sumber Daya Alam sektor Pertanian yang sudah dikelola meliputi hasil padi, palawija, sayuran dan buah-buahan. Sesuai data yang ada, hasil pertanian rata-rata tiap tahun di Desa Purwodadi yang banyak adalah hasil padi yaitu sebanyak 6 Ton/Ha, untuk hasil palawija sekitar 2,5 Ton/Ha, sedangkan untuk hasil tanaman sayuran dan buah-buahan hanya sekitar 1,5 Ton/Ha.(Purwodadi, 2017)

Dilihat dari luas area pertanian yang dimiliki Desa Purwodadi hasil pertanian rata-rata tiap tahun tersebut belumlah maksimal. Oleh karena itu melalui RPJMDes ini seluruh warga Desa berharap pemerintah dapat memberikan perhatian dalam upaya peningkatan hasil-hasil pertanian di desa terutama terkait permasalahan kekurangan air irigasi yang selama ini sangat dirasakan oleh para petani di desa.(Purwodadi, 2017)

Keadaan prasarana sampai saat ini telah memiliki ruas jalan sepanjang 15 $\mathrm{km}$, saluran irigasi sepanjang $3 \mathrm{~km}$, pasar desa, sumber air bersih dan sarana prasarana pendukung lainnya. Sampai dengan saat ini pelayanan masyarakat yang 
berkaitan dengan kependudukan, perijinan, ketentraman dan ketertiban umum berjalan dengan baik. Hal ini dapat ditunjukkan dengan jumlah perangkat desa yang cukup memadai. Untuk kondisi ruas jalan sepanjang tersebut $\pm 8 \mathrm{~km}$ masih berupa jalan tanah dan $\pm 3 \mathrm{~km}$ berupa jalan telford. Sedangkan kondisi pasar desa yang ada belum bersifat permanen, demikian juga masalah air bersih dan sanitasi belum dekelola dengan baik.

Penelitian yang dilakukan oleh Rizqie Auliana, Siti Hamidah, Fitri Rahmawati, dan Mutiara Nugraheni dengan judul "Pengembangan Olahan Tahu dan Limbahnya Berbasis Teknologi Pengawetan Menuju Diversifikasi Produksi Pasca Erupsi”. Pada penelitian dinyatakan bahwa limbah industri tahu dibagi menjadi limbah cair dan limbah padat. Selama ini limbah padat masih bisa dimanfaatkan dan tidak mengganggu pencemaran lingkungan sebagai pakan ternak dan juga bisa dimanfaatkan menjadi tempegembus. Pakan ternak maupun tempe gembus relatif bernilai rendah atau murah jika dijual. Inovasi peneliti menjadikan limbah padat industri tahu dijadikan bahan makanan yang awet dan tahan lama seperti untuk campuran pembuatan kerupuk dan diawetkan menjadi tepung sehingga mempunyai nilai jual yang tinggi. Sedangkan untuk limbah cair industri tahu yang dianggap sangat mencemari lingkungan, peneliti membuat inovasi menjadikan limbah cair menjadi Nata de Soya, sehingga pembuatan Nata de Soya menumbuhkan industri baru serta mengurangi jumlah pengangguran.(Auliana, Hamidah, Rahmawati, \& Nugraheni, 2013)

Di Desa Purwodadi Dusun Tempurejo RT 02 RW 02 khususnya, terdapat masalah yang sampai saat ini belum menemukan solusi. Masyarakat Desa Purwodadi Dusun Tempurejo mayoritas bekerja sebagai petani dan Buruh. Sebenarnya, Desa Purwodadi Dusun Tempurejo memiliki potensi yang cukup baik, seperti melimpahnya produksi tahu, tempe, cabai, buah naga, jeruk, padi, dan lainya. Namun banyak kendala yang menyebabkan dusun ini lambat berkembang, diantaranya ialah murahnya pemasaran hasil panen serta tidak ada lembaga pengelola potensi alam, sehingga masyarakat Dusun Tempurejo hanya 
mengandalkan harga jual tengkulak yang hanya di jual mentah. Hal ini disebabkan tidak adanya tenaga ahli dan kelompok masyarakat yang mengolah hasil bumi. Selain itu masyarakat Dusun Tempurejo kurang memiliki koneksi dari pihak luar untuk menjual hasil panen yang diperoleh.(Purwodadi, 2017)

Tidak adanya kelompok usaha mikro atau koperasi petani juga menjadi kendala berarti bagi warga Dusun Tempurejo. Karena bagaimanapun juga, segala bentuk kegiatan pertanian seharusnya memiliki wadah atau koperasi yang mampu mengolah. Dikatakan penghasilan masyarakat Desa Purwodadi Dusun Tempurejo cukup untuk memenuhi kebutuhan sehari-hari karena di dusun ini banyak tersedia sumber bahan pokok yang bisa di konsumsi seperti: cabai, jeruk, buah naga, dan lainya.(Purwodadi, 2017)

Salah satu upaya untuk membangkitkan pemikiran yang kurang berkembang penduduk Desa Purwodadi Dusun Tempurejo adalah dengan memberikan kepercayaan akan produk-produk yang bisa mereka hasilkan dari kreatifitas tangan mereka. Dengan melihat potensi desa yang sebagian besar adalah perkebunan, baik itu cabai, jeruk, buah naga serta produksi tahu dan tempe, tak lupa inti bahan dasar yang akan kami teliti adalah ampas tahu.

Setelah melakukan observasi, melihat begitu banyaknya potensi yang ada, salah satunya yakni produksi tahu yang menyisakan ampas yang biasanya hanya digunakan untuk makanan sapi. Dewasa ini, permasalahan di Indonesia, khususnya di bidang ekonomi dan kesejahteraan masyarakat kian meningkat. Tingkat pengangguran di Indonesia dari tahun ke tahun mengalami peningkatan yang signifikan. Hal ini dikarenakan semakin kecilnya lapangan pekerjaan bagi masyarakat Indonesia. Hal ini bisa memacu untuk berfikir bagaimana menciptakan lapangan pekerjaan sendiri atau berwirausaha dengan tujuan membuka peluang kerja bagi masyarakat walaupun secara sederhana.(Wirawan, Suliana, \& Iskandar, 2017)

Melalui kegiatan ini ada ide untuk membuat kerupuk ampas tahu atau bisa dikatakan bungkil kedelai yang masih jarang ditemui di masyarakat dan memiliki 
keunikan dibandingkan dengan kerupuk pada umumnya. Saya berharap, rencanarencana yang sudah disusun dapat terwujud dan menjadi wacana produk baru di masyarakat.

Keberadaan kerupuk merupakan salah satu lauk yang di gemari masyarakat. Kini, sesuai dengan perkembangan zaman, keberadaan kerupuk juga semakin berkembang baik dari segi rasa nya yang mulai beraneka ragam maupun bentuknya.

Adapun tujuannya yakni, membuat jajanan yang sehat, bergizi dan mengenyangkan bagi masyarakat, menciptakan Kerupuk Bungkil Kedelai yang tinggi protein, dan karbohidrat, mencari keuntungan atau laba, mencapai target penjualan, dan menciptakan lapangan kerja.

Strategi yang akan lakukan untuk memulai usaha ini adalah mensosialisasikan program kepada ibu PKK dan ibu-ibu sekitar, demonstrasi program bersama ibu-ibu, memasarkan produk.

Adapun kendala-kendala yang dihadapi dari permasalah diatas adalah sebagai berikut:

1. Tidak pastinya cuaca panas, padahal pembuatan kerupuk sangat memerlukan panas matahari

2. Keterbatasan alat pembuatan kerupuk

Berdasarkan beberapa permasalahan hasil observasi diatas, dapat di ambil kesimpulan bahwa bungkil kedelai merupakan potensi yang dapat dikembangkan guna meningkatkan perekonomian petani, khususnya produksi tahu di Dusun Tempurejo Desa Purwodadi. 
202 | Dampingan Komunitas Pengusaha Tahu Melalui Pemanfaatan Bungkil ...

\section{Kerangka Masalah}

\section{Pohon Masalah}

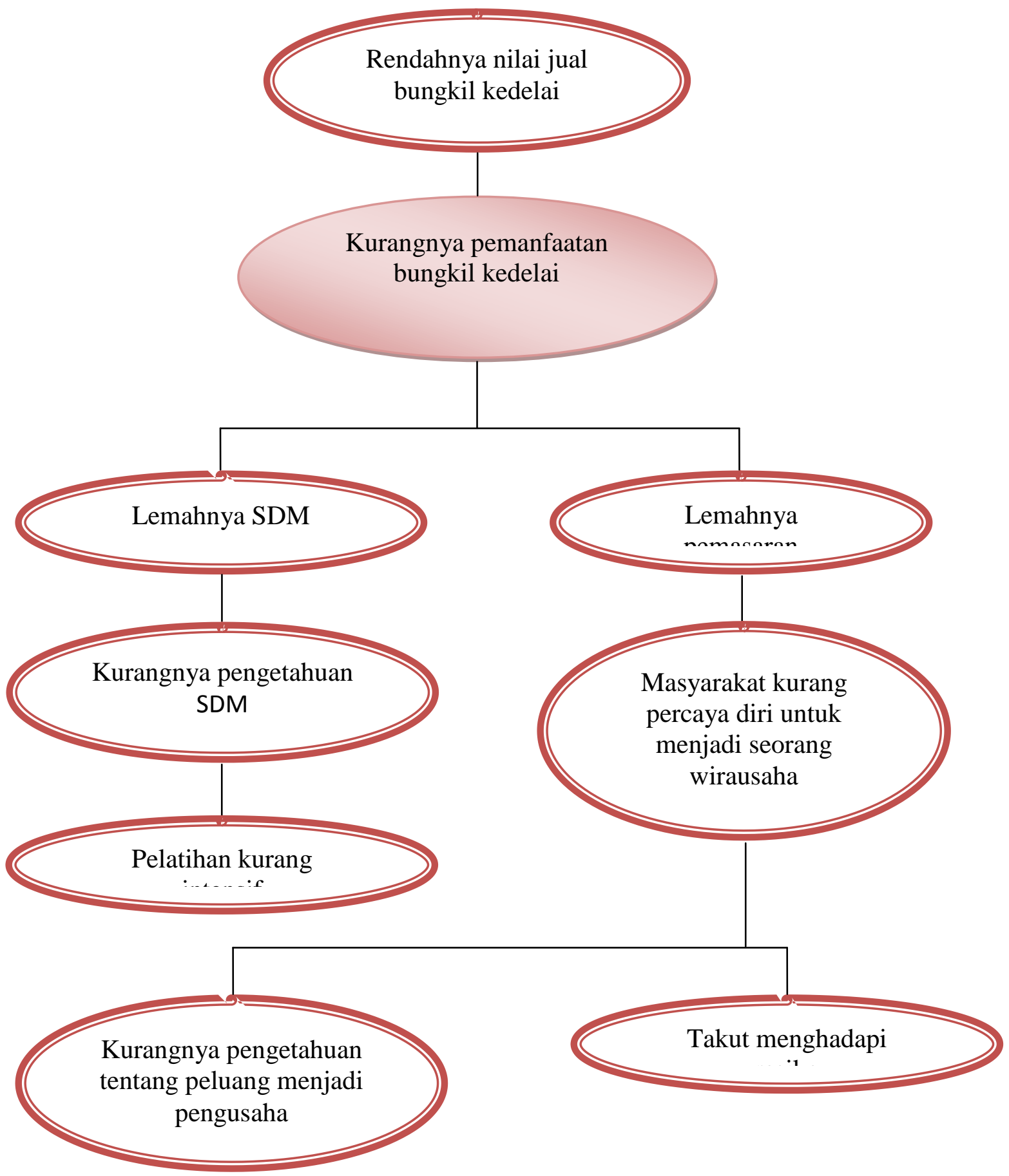

Gambar 1. Pohon masalah Desa Purwodadi 




Gambar 2. Pohon Harapan Desa Purwodadi 
204 | Dampingan Komunitas Pengusaha Tahu Melalui Pemanfaatan Bungkil ...

\section{Metode}

Tidak hanya sebuah pendekatan saja yang diperlukan untuk menunjang keberhasilan program yang direncanakan melainkan harus adanya sebuah tindakan yang harus segera dilakukan, dalam program yang dicanangkan untuk membuka sebuah wacana baru dalam bidang ekonomi melihat potensi yang melimpah di Desa Purwodadi diantaranya adanya beberapa masyarakat yang memproduksi tahu dan tempe, akan tetapi kurangnya minat masyarakat untuk mengolah kembali bungkil kedelai yang menjadikan rendahnya nilai bungkil kedelai yang ada di Desa Purwodai karena biasanya bungkil kedelai dijadikan sebagai makanan sapi, oleh karena itu perlunya ada inovatif baru yang dapat membantu meningkatkan nilai jual bungkil kedelai.

Saya mencoba mengolah bungkil kedelai yang didapat dari salah satu pengelola tahu di Desa Purwodadi menjadi sebuah makanan yang mayoritas disukai masyarakat dengan menggunakan tema Mengolah ampas tahu menjadi kerupuk bungkil kedelai untuk meningkatkan nilai jual bungkil kedelai di Purwodadi. Kelayakan Sasaran Dalam rangka melaksanakan tugas saya mengambil judul "Pemanfaatan Bungkil Kedelai menjadi Kerupuk untuk Meningkatkan Nilai Jual Bungkil Kedelai Di Desa Purwodadi” karena Desa Purwodadi berpotensi sebagai produksi tahu dan tempe hampir sebagian besar masyarakat khususnya Dusun Tempurejo, dan dengan ini saya mempunyai inisiatif untuk memanfaatkan bungkil kedelai sebagai kerupuk yang mempunyai daya jual yang lebih tinggi, karena sebagian masyarakat memanfaatkan bungkil kedelai sebagai gembos, pakan ternak sapi dan bebek yang harganya sangatlah murah. Dari program tersebut muncullah beberapa sasaran program yang akan menjadi pendukung terlaksananya program ini adapun khalayak dalam program ini yang berjudul "Pemanfaatan Bungkil Kedelai menjadi Kerupuk untuk Meningkatkan Nilai Jual Bungkil Kedelai di Desa Purwodadi”.(Wirawan et al., 2017) Dalam melakukan suatu program PAR diperlukan suatu strategi, yaitu: 
1. Melakukan observasi salah satu tempat pembuatan tahu yang ada di Dusun Tempurejo

2. Melakukan Koordinasi kepada Salah satu warga yang biasa membuat kerupuk

3. Koordinasi dengan ibu kepala desa

4. Melakukan percobaan pembuatan kerupuk bungkil kedelai sebelum di sosialisasikan kepada masyarakat

5. Merencanakan konsep acara sosialisasi kepada masyarakat

6. Menyebarkankan undangan kepada ibu PKK dan masyarakat untuk mengikuti sosialisasi pembuatan kerupuk bungkil kedelai

7. Menyiapkan segala kebutuhan yang diperlukan pada saat sosialisasi

8. Melakukan sosialisasi pembuatan kerupuk bungkil kedelai kepada ibu PKK yang ada di Desa Purwodadi

9. Melakukan pengemasan agar menambah kerupuk bungkil kedelai semakin menarik

\section{Hasil dan Diskusi}

Melihat banyaknya produsen tahu di Desa Purwodadi terutama di Dusun Tempurejo selain berefek ekonomi yang sejahtera untuk masyarakat sekitar, juga memiliki limbah yang masih dapat dimanfaatkan. Limbah tersebut yaitu limbah air dan limbah ampas tahu atau biasa disebut dengan bungkil kedelai. Limbah air tahu itu, disalurkan ke sungai dan juga biasa dimanfaatkan sebagai minuman ternak. Sementara bungkil kedelai diolah menjadi tempe gembos dan dimanfaatkan sebagai pakan ternak dengan harga yang sangat ekonomis. Setiap satu bungkus tempe gembos dijual seharga Rp. 500,- sedangkan setiap satu drum bungkil kedelai dipatok seharga Rp 1.000,00 - Rp 1.500,00.

Dari sini muncullah sebuah pemikiran untuk mengolah bungkil kedelai menjadi sebuah produk makanan yang bernilai ekonomi lebih tinggi. Kami memilih mengolahnya menjadi produk makanan dikarenakan peluang bisnis dalam 
bidang olahan makanan memang sangat menjanjikan. Disamping itu, meskipun bungkil kedelai merupakan limbah dari pengolahan tahu, didalamnya masih mengandung protein dan zat besi.(Wirawan et al., 2017)

Setelah kami mempertimbangkan dengan matang, kami berinisiatif mengolah bungkil kedelai menjadi "Kerupuk Bungkil Kedelai" yang sehat dan digemari oleh masyarakat. Dengan cara pengolahan yang tepat, kami yakin produk sederhana ini akan memiliki prospek yang baik kedepan, utamanya untuk masyarakat Desa Purwodadi.

\section{Businessplan}

Visi

Visi dari pembuatan kerupuk bungkil kedelai ini adalah:

1) Memanfaatkan limbah produksi tahu yang selama ini belum dimanfaatkan dengan baik oleh masyarakat.

2) Memperkenalkan inovasi pengolahan bungkil kedelai kepada masyarakat Desa Purwodadi.

3) Memberdayakan ibu-ibu PKK agar lebih kreatif dan inovatif.

Misi

Misi dari usaha pembuatan kerupuk bungkil kedelai ini adalah:

1) Membuat kerupuk dari bungkil kedelai dengan pengolahan yang tepat.

2) Melaksanakan demonstrasi pembuatan kerupuk bungkil kedelai kepada masyarakat dan ibu-ibu PKK

3) Mengajak ibu-ibu PKK untuk meneruskan produksi kerupuk bungkil kedelai sebagai penghasilan tambahan bagi organisasi.

Adapun tujuan dari produksi kerupuk bungkil kedelai ini adalah:

a. Melaksanakan tujuan program pemberdayaan masyarakat

b. Merealisasikan program yaitu memanfaatkan potensi yang ada di Desa Purwodadi dengan maksimal

c. Membuat produk makanan ringan yang enak, sehat, dan ekonomis berbahan dasar bungkil kedelai 
d. Mendongkrak perekonomian masyarakat Desa Purwodadi dengan laba yang menjanjikan dari hasil penjualan kerupuk bungkil kedelai analisis usaha

Bahan Baku dan Penggunaanya

Bahan-bahan yang dibutuhkan dalam pembuatan kerupuk bungkil kedelai adalah:

1) $1 \mathrm{~kg}$ tepung tapioka

2) $1 / 4 \mathrm{~kg}$ bungkil kedelai

3) 1 bungkul bawang putih

4) $3 \mathrm{sdm}$ garam

5) 1 ons udang kecil

6) 3 gelas air

7) $1 \mathrm{~L}$ minyak goreng

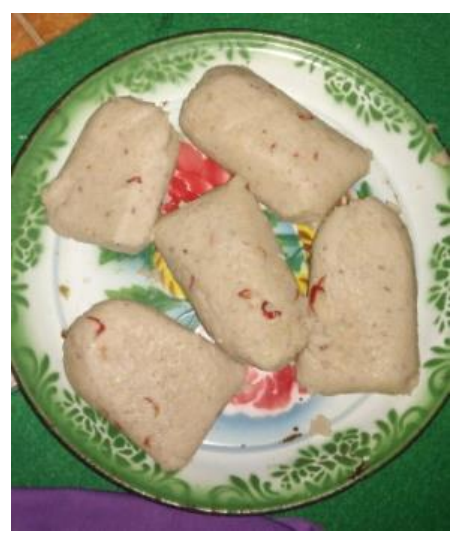

Gambar 1 Kerupuk Ampas Tahu setelah pengukusan

\section{Proses Produksi}

Cara membuat kerupuk bungkil kedelai sangatlah mudah, berikut cara membuatnya:

1) Haluskan bawang putih, garam dan udang kecil

2) Masak $1 / 4$ tepung tapioka, 3 gelas air, dan bumbu yang telah dihaluskan dalam wajan sampai kalis seperti lem

3) Tuangkan seluruh adonan yang telah dimasak dalam wadah berisi $3 / 4$ tepung tapioka 
208 | Dampingan Komunitas Pengusaha Tahu Melalui Pemanfaatan Bungkil ...

4) Aduk (uleni) hingga merata

5) Ambil segenggam adonan bentuk bola dalam tangan dengan cara diputarputar (jawa:diglintiri) kemudian bulat panjang

6) Masukkan air dalam wajan yang telah digunakan sebelumnya untuk merebus adonan yang telah dibentuk tadi

7) Rebus hingga adonan matang yaitu ketika adonan naik dan warnanya kecoklatan semua.

8) Tiriskan selama sehari dan iris tipis

9) Jemur kerupuk hingga benar-benar kering dan goreng dalam $1 \mathrm{~L}$ minyak goreng

\section{Kesimpulan}

Setelah melakukan observasi dan melaksanakan program pengabdian pada masyarakat di Desa Purwodadi selama kurang lebih 30 hari, dapat diidentifikasi bahwa banyak potensi yang bisa dikembangkan di Desa Purwodadi ini, salah satunya adalah produksi tahu dan tempe. Produk "kerupuk bungkil kedelai" ini telah dipromosikan langsung oleh Ibu Kepala Desa Purwodadi untuk dikembangkan masyarakat desa, dimulai dari ibu-ibu PKK, ibu-ibu rumah tangga dan ibu-ibu yang ingin membuka wirausaha. Program ini dapat berjalan sukses karena didukung dengan adanya potensi alam yang berlimpah berupa ampas tahu (bungkil kedelai) yang menjadi bahan utama dari program ini. Sehingga dapat dimanfaatkan untuk meningkatkan perekonomian masyarakat Desa Purwodadi.

\section{Daftar Pustaka}

Auliana, R., Hamidah, S., Rahmawati, F., \& Nugraheni, M. (2013). Pengembangan olahan tahu dan limbahnya berbasis teknologi pengawetan menuju diversifikasi produksi pasca erupsi. INOTEKS, 17(2).

Purwodadi, K. D. (2017). Buku Profil Desa Purwodadi 2017. Banyuwangi: Desa 
Purwodadi.

Wirawan, W., Suliana, G., \& Iskandar, T. (2017). Pemanfaatan Ampas Tahu Untuk Olahan Pangan dari Limbah Pengolahan Industri Tahu di Kelurahan Tunggulwulung Kota Malang. JAPI (Jurnal Akses Pengabdian Indonesia), 2(1), 64-70. 
210 | Dampingan Komunitas Pengusaha Tahu Melalui Pemanfaatan Bungkil ... 